even fatal. Further, an $R h$-negative woman may have been sensitized by having an $R h$-positive baby, or by a transfusion of $R h$-positive blood; if she then has an $R h$-positive child, there is increased risk of erythroblastosis or of an allied condition in this child. Also, if an $R h$-negative mother has an $R h$-positive child and is sensitized by this child, her first trans. fusion of $R h$-positive blood may cause an incom. patibility reaction. American work has shown that this $R h$-sensitivity may last for eight to twenty-two years. In addition to this, anti- $R h$ agglutinins cannot yet be always detected in the blood. R. R. A. Coombs, R. E. Mourant and R. R. Race have, however (Lancet, 15, July 7, 1945), described a new method of detecting weak and 'incomplete' $R h$ agglutinins in the blood (cf. also Coombs, R. R. A., and Race, R. R., Nature, 156, 233 (1945) and the discussions by A. J. MeCall and S. Holdsworth in Nature, 155, 788 (1945) of hæmolytic disease of the newborn due to the antibody $S t$, H. S. Baar (ibid., 789) on the Race-Wiener test in hæmolytic disease of the new-born, and G. Plaut, M. Barrow and J. M. Abbott (Brit. Med. J., 273, Sept. 1, 1945) ).

The further difficulties of this problem and the measures to be taken to avoid the risks concerned are discussed in the Lancet (loc. cit.). Obviously they are matters for the expert, and everyone will support the conclusion that blood-grouping, especially when it is related to maternity work, can no longer be left in the hands of an individual pathologist, who may be employed upon this work only for part of his time; nor can supplies of $R h$-negative blood be left to small panels of local donors. The post-war blood-transfusion service will have to be very carefully organized, not only to meet the known risks involved, but also to provide research facilities and personnel on a scale adequate to the future public importance of the whole problem. Blood-transfusion sources available during the War have provided one of the outstanding examples of the beneficence of scientific discovery. It would indeed be an indictment of our civilization if, now that peace has returned, we failed to give this particular service every encouragement and facility possible.

\section{Religious Instruction in Schools}

A Commrtee of Representatives of the Joint Conference of Anglicans and Free Churchmen, the Association of Education Committees and the National Union of Teachers has prepared a pamphlet entitled "A National Basic Outline of Religious Instruction" (London: National Union of Teachers, 1945. 2d.). The pamphlet calls to mind an article bearing the above heading which appeared in Nature of November 14, 1942. Much has happened since then, but the article still stands as an explanation of the reasons why a scientific journal should in its own way deal with the problem of religious education. In particular, we retain the conviction that, after all is said and done, the psychological core of the problem lies in the relation of the teacher and the pupil, and that unless one can trust the teachers no precautions will avail. Choose the teachers carefully, train them adequately, and then trust them. The liberty of the well-prepared teacher is the essential condition.

The pamphlet is not a syllabus, but a broad 'outline' of the kinds of material that may by common consent be used in the making of a syllabus. The outline is quite unique in being national, not local (a national syllabus is an absurd idea, but a national outline is another matter). It is unique also in having been prepared by a committee in which teachers were on equal terms with religious bodies and education authorities. The outline repeatedly states that the true interests of the children have ever been paramount in its production. It might be added in the same breath that the liberty of the teacher is the only way to secure the true interests of the children. The idea of the broad outline, which makes no pretence whatever to be a syllabus, suitable for any school, any teacher, and any social environment, has enabled the committee to make suggestions, especially for the older pupils, in directions that will be welcomed in many quarters, such as comparisons of Christian beliefs with those of other religions, the Bible and science, miracles, and problems of personal and social ethics. "The spirit of enquiry," says the Committee, "should be welcomed, stimulated and fostered." That one sentence sums up the reasons for giving strong approval to this basic outline.

\section{British Bryological Society}

ON September 12 the British Bryological Society held its first meeting since June 1939. It was announced that, during the War, the Society lost eighteen members, including H. N. Dixon, P. Allorge, W. E. Nicholson, H. H. Knight, C. H. Binstead and H. G. Jameson; new members during the same period total nearly forty. It has not been possible to renew contact with more than a few of the Continental members. It was decided to have a distribution of specimens during the coming winter, and the time of the next meeting was fixed for about Easter 1946, with a second one to be held during the winter following. Suggestions concerning biological observations on bryophytes which might be usefully undertaken by members were put forward and considered. The advisability of publishing new editions of the Census Catalogues of British Mosses and Hepatics was left to the decision of a special committee. On September 13, Dr. S. Wyard led a party of twenty-eight members on a ramble in the neighbourhood of Newlands Corner in Surrey. Although not a rich district bryologically, it yielded a few interesting plants, including the rare Dicranum strictum Schleich., a recent addition to the flora of Britain. In the evening the party gathered at the South London Botanical Institute to hear Dr. P. W. M. Richards give a talk on "The Growing and Cultivation of Bryophytes". Those interested in mosses or liverworts can obtain particulars of the objects of the Society and conditions of membership from the secretary, Mr. A. Thompson, 23 Regent Crescent, Skipton, Yorkshire.

\section{Announcements}

Dr. Herman Shaw, keeper in the Science Museum, has been appointed director and secretary of the Museum in succession to Colonel E. E. B. Mackintosh, who will retire on November 30 .

Dr. J. S. H. DAvies, formerly of Imperial Chemical Industries, Ltd., has taken up his duties as director of research of the British Schering Research Institute in succession to Prof. D. H. Hey, who was recently appointed to the chair of chemistry, King's College, University of London.

ERratum.-In the communication by Prof. S. V. Kravkov and L. P. Galotchkina ontitled "Electrotonus in Colour Vision" published in Nature of May 19, 1945 (p. 605), the current used was $0.02 \mathrm{~mA}$., and not $0.2 \mathrm{~mA}$. as stated in the penultimate line of the first column. 